\title{
AKTIVITAS DAN KANDUNGAN METABOLIT SEKUNDER AKTIF FRAKSI ISOLAT ETIL ASETAT DAUN TENDANI (GONIOTHALAMUS MACROPHYLLUS HOOK.F.THOMS.) ASAL PENAJAM PASER UTARA
}

\author{
Arsyik Ibrahim \\ Bagian Biologi-Mikrobiologi Farmasi Fakultas Farmasi, \\ Universitas Mulawarman, Samarinda, Kalimantan Timur \\ Email : achie.ibrahim@gmail.com
}

\begin{abstract}
Research has been carried the title activity and the content of secondary metabolites isolated active fractions of ethyl acetate leaf extract tendani from Penajam Paser Utara. This research objective is to know antibacterial activity from ethyl acetate fraction of tendani leaves for bacteria with TLC-Bioautoghraphy method, antioxidant activity from ethyl acetate fraction of tendani leaves for DPPH and identify the content of secondary metabolites from ethyl acetate fraction of tendani leaves. Result obtained ethyl acetate fraction isolates have antibacteria activity against bacteria Salmonella thyposa, Staphylococcus aureus, Eschericia coli, Pseudomonas aeruginosa, ethyl acetate fraction isolates tendani leaves have antioxidant activity seen happen DPPH andactivity secondary metabolites from ethyl acetate isolated fraction was alkaloids, flavanoids, steroids, terpenoids and phenolics.
\end{abstract}

Keybord : Leaf extract tendani, Ethyl acetate isolate fraction, antibacterial activity, TLCBioautoghraphy

\begin{abstract}
ABSTRAK
Telah dilakukan penelitian aktivitas dan kandungan metabolit sekunder aktif fraksi isolat etil asetat daun Tendani (Goniothalamus Macrophyllus Hook.F. \& Thoms) Asal Penajam Paser Utara. Penelitian ini bertujuan untuk mengetahui aktivitas antibakteri fraksi aktif etil asetat terhadap bakteri uji dengan metode KLT Bioautografi, mengetahui aktivitas antioksidan fraksi aktif etil asetat terhadap DPPH dan mengetahui golongan metabolit sekunder aktif terdapat dalam fraksi aktif etil asetat daun tendani. Hasil penelitian diperoleh fraksi isolat etil asetat memiliki aktivitas terhadap bakteri Streptococcus mutans, Staphylococcus aureus, Eschericia coli, Pseudomonas aeruginosa, fraksi isolat etil asetat daun tendani memiliki aktivitas antioksidan berdasarkan reaksi peredaman DPPH. Golongan metabolit sekunder aktif fraksi isolat etil asetat adalah alkaloid, flavanoid, steroid, terpenoid dan fenolik.
\end{abstract}

Kata kunci : Daun tendani, fraksi isolat etil asetat, aktivitas antibakteri, KLT Bioautografi

\section{PENDAHULUAN}

Infeksi merupakan salah satu penyebab utama penyakit di dunia terutama di daerah tropis, seperti Indonesia. Kasus infeksi disebabkan mikroba patogen masuk ke dalam jaringan tubuh dan berkembang biak di dalam jaringan (Waluyo, 2008). Kejadian penyakit 
infeksi semakin meluas dan beragam, sehingga penggunaan antimikroba juga meningkat. Tanpa memerhatikan prinsip-prinsip penggunaan antimikroba secara serius, rasional, dan konsisten akan menimbulkan kerugian material, efek samping dan resistensi yang sangat besar.

Timbulnya berbagai jenis infeksi mendorong pentingnya penggalian sumber antibakteri dari alam. Tanaman diketahui berpotensi sebagai obat alternatif pada berbagai penyakit infeksi. Selain itu, pengobatan herbal dipercaya lebih aman dibandingkan menggunakan bahan kimia sintesis.

Salah satu tanaman yang secara empiris digunakan oleh Kabupaten Penajam Paser Utara dalam pengobatan infeksi adalah daun tendani (Goniothalamus macrophyllus. Hook.f. \& Thoms). Daun tendani ini memiliki kandungan senyawa alkaloid, saponin, tannin dan fenol. Dimana senyawa tersebut berpotensi terhadap aktivitas antibakteri (Abdi,2011)

Menurut Alifin Taufik (2011), fraksi etil asetat daun tendani memiliki aktivitas terhadap bakteri uji staphylococcus aureus dan pseudomonas aeruginosa pada konsentrasi $8 \%$ dengan diameter zona hambat yaitu 10,62 mm dan 10,92 mm. Menurut Devy Agustina Arianto (2012), fraksi etil asetat daun tendani memiliki aktivitas antioksidan dengan nilai $\mathrm{IC}_{50}$ yaitu $218,86 \mathrm{ppm}$.

Data-data hasil penelitian tumbuhan tendani diatas perlu dilakukan pengembangan penelitian melalui isolasi fraksi etil asetat sekaligus menguji efek antibakteri dan efek antioksidan.

\section{METODE PENELITIAN}

\section{Bahan}

Bahan yang diteliti adalah Daun Tendani dengan bentuk ekstrak etil asetat, bahan penelitian adalah : aquades, metanol, n-heksana, etil asetat, kloroform. Pereaksi asam sulfat $10 \%$, pereaksi DPPH, medium NA, $\mathrm{NaCl}$ 0,9\%, Aluminium foil, Silika Gel 60, Silika Gel GF 254, bakteri Staphylococcus aureus, bakteri Salmonella thyposa, Escherichia coli, Pseudomanas aeruginosa dan pereaksi semprot.

\section{Alat}

Ose, spoit, rak tabung, tabung reaksi, pipet gondok / pipet volume, toples kaca, corong pisah, Erlenmeyer, gelas kimia, chamber, cawan Petri, kolom kromatografi vacum cair, spray penyemprot reagen, bunsen, rotary evaporator, water bath, timbangan analitik (and gf 300), oven (memmert), inkubator (memmert), autoclave, lampu UV 254 dan 366 nm.

\section{Prosedur Pengambilan dan Pengolahan Sampel}

Bahan yang diteliti adalah tumbuhan daun tendani. Tempat pengambilan sampel terletak dipenajam paser utara. Pengambilan sampel dilakukan pagi hari. Sampel dibersihkan, dicuci, dipotong-potong kemudian dikeringkan tanpa melalui sinar matahari.

\section{Prosedur Ekstraksi, fraksi-fraksi dan fraksi isolat}

Simplisia yang telah dirajang dimasukan ke dalam wadah toples, lalu diberi cairan pengekstrak berupa metanol sampai simplisia terendam secara sempurna. Proses ekstraksi berlangsung selama 2 × 24 jam, hasil ekstrak disaring menggunakan kertas saring lalu ditampung ke dalam wadah kaca, kemudian simplisia kembali direndam dengan menggunakan pelarut metanol yang baru, diulangi proses ekstraksi hingga hasil ekstraksi berwarna bening. Selanjutnya difraksinasi dengan menggunakan fraksinasi cair-cair. Ekstrak kering metanol kemudian dilarutkan dengan air selanjutnya dimasukkan pelarut $n$ - 
heksana ke dalam corong pisah, sampai terbentuk 2 lapisan. Selanjutnya di tampung fase $n$-heksana bebas air dalam wadah penampung, kemudian dipekatkan dengan menguapkan. Fase air yang tersisa dari fase $n$-heksan ditambahkan dengan etil asetat dalam corong pisah, sampai terbentuk 2 lapisan, kemudian di tampung fase etil asetat bebas air dalam wadah penampung, kemudian dipekatkan dengan menguapkan.

Ekstrak etil asetat selanjutnya dilakukan fraksinasi dengan menggunakan metode Kromatografi Vacum cair, melalui 2 tahap yaitu : tahap pertama ekstrak etil asetat difraksinasi KVC didapatkan 4 fraksi gabungan yaitu fraksi A, B, C dan D. Empat fraksi selanjutnya diuji aktivitas antibakteri KLT bioautografi dan diperoleh fraksi B aktif terhadap bakteri uji ekstrak etil asetat selanjutnya difraksinasi kembali dengan KVC, diperoleh 4 fraksi isolat gabungan yaitu fraksi $\mathrm{B}_{1}, \mathrm{~B}_{2}, \mathrm{~B}_{3}$ dan $\mathrm{B}_{4}$. Isolat yang diperoleh dari KVC II, selanjutnya diuji kembali aktivitas antibakteri menggunakan KLT bioautografi.

\section{Prosedur Pengujian Aktivitas Antibakteri}

Fraksi isolat $\mathrm{B}_{1}(2: 1)$ dan $\mathrm{B}_{2}(1: 10,1: 2,1: 1)$ ditotolkan pada plat KLT, selanjutnya dielusi dengan eluen 35:1 (kloroform : metanol) untuk fraksi isolat $\mathrm{B}_{1}$ dan 25:1 (kloroform : metanol) untuk fraksi isolat $B_{2}$. Disiapkan medium agar (NA) dan dimasukkan biakan bakteri uji. Plat KLT yang telah dielusi diletakkan pada permukaan medium selama \pm 1 (satu) jam, selanjutnya medium diinkubasi pada suhu $37^{\circ} \mathrm{C}$ selama 24 jam. Diamati zona bunuh yang terbentuk pada medium. Hasil positif ditandai dengan adanya zona bening pada daerah sekitar spot senyawa hasil elusi.

\section{Prosedur Pengujian Aktivitas Antioksidan}

Pengujian aktivitas antioksidan dilakukan secara kualitatif yaitu penyemprotan larutan DPPH pada plat KLT yang telah ditotolkan ekstrak isolat etil asetat daun tendani. Penyemprotan pereaksi DPPH dilakukan diruang gelap. Hasil positif ditunjukkan dengan peredaman warna ungu hasil penyemprotan DPPH pada spot hasil elusi.

\section{Pengujian Kandungan Metabolit Sekunder Aktif}

Identifikasi golongan metabolit sekunder isolat dilakukan dengan penyemprotan reagen tertentu, sebelumnya masing-masing fraksi isolat ditotolkan pada plat KLT dan dielusi dengan eluen Kloroform : Metanol (25:1). Plat yang telah terelusi selanjutnya disemprot dengan masing-masing pereaksi spesifik untuk mendeteksi ada tidaknya kandungan metabolit sekunder dari masing-masing isolat. Pereaksi spesifik yang digunakan adalah Dragendorf untuk reaksi alkaloid, timbal asetat $25 \%$ untuk reaksi flavonoid, asam fosfat $85 \%$ untuk reaksi steroid, Lieberman Bouchardt untuk reaksi triterpenoid dan timah (IV) klorida untuk reaksi fenol. Hasil positif berdasarkan reaksi warna spesifik pada sinar tampak UV $366 \mathrm{~nm}$.

\section{HASIL DAN PEMBAHASAN}

\section{Aktivitas Antibakteri Fraksi Isolat Aktif Etil asetat}

Ekstrak etil asetat etil asetat diisolasi dengan metode KVC. Hasil KVC 1 diperoleh 4 fraksi yaitu fraksi A, B, C, D, fraksi-fraksi B dan D dilakukan pengujian antibakteri dengan metode KLT Bioautografi dan diperoleh fraksi B yang memiliki aktivitas antibakteri. Selanjutnya fraksi aktif B diisolasi kembali dengan KVC ke-2, dan diperoleh 4 fraksi berdasarkan profil KLT yaitu fraksi $\mathrm{B}_{1}, \mathrm{~B}_{2}, \mathrm{~B}_{3}$ dan $\mathrm{B}_{4}$. Fraksi $\mathrm{B}_{1}$ dan $\mathrm{B}_{2}$ selanjutnya diuji aktivitas terhadap bakteri Staphylococcus aureus, Escherichia coli, Streptococcus mutans dan Pseudomonas aeruginosa. Eluen yang digunakan untuk elusi adalah 25:1 untuk fraksi $\mathrm{B}_{2.1}, \mathrm{~B}_{2.2}$ dan $\mathrm{B}_{2.3}$ dan 35:1 untuk fraksi $\mathrm{B}_{1.1}$. Berdasarkan hasil uji KLT Bioautografi fraksi $\mathrm{B}_{1.1}, \mathrm{~B}_{2.1}, \mathrm{~B}_{2.2}$ dan $\mathrm{B}_{2.3}$ daun tendani dinyatakan memiliki aktivitas 
sebagai antibakteri, yang ditandai dengan terbentuknya zona penghambatan pertumbuhan bakteri uji pada permukaan medium. Aktivitas antibakteri isolat aktif daun tendani dapat dilihat pada Tabel 1.

\begin{tabular}{cccc}
\hline No & Fraksi Isolat (Eluen) & Nilai Rf & $\begin{array}{c}\text { Hasil Pengamatan } \\
\text { Positif }\end{array}$ \\
\hline 1 & $2: 1\left(\mathrm{~B}_{1.1}\right)$ & 6,5 & EC \\
& & 5 & SA \\
& $1: 10\left(\mathrm{~B}_{2.1}\right)$ & 1 & SA \\
\hline 2 & & 6,5 & SA, EC, SM, PA \\
& & 6 & SA, EC, PA \\
& $1: 2\left(\mathrm{~B}_{2.2}\right)$ & 4 & SA, EC, PA \\
& $1: 1\left(\mathrm{~B}_{2.3}\right)$ & 6,7 & SM \\
\hline 3 & 5 & SM, PA \\
& & 6,5 & SA, EC, PA \\
\hline 4 & & & SA, EC, SM, PA \\
\hline
\end{tabular}

Keterangan Tabel 1:

SA : Staphylococcus aureus

EC : Escherichia coli

SM : Streptococcus mutans

PA : Pseudomonas Aeruginosa

$2: 1$ : Fraksi Isolat $\mathrm{B}_{1.1}$

$1: 10$ : Fraksi Isolat $\mathrm{B}_{2.1}$

$1: 2$ : Fraksi Isolat $\mathrm{B}_{2.2}$

$1: 1$ : Fraksi Isolat $\mathrm{B}_{2.3}$

\section{Aktivitas Antioksidan Fraksi Isolat Aktif}

Aktivitas antioksidan dilakukan dengan metode DPPH. Antioksidan merupakan senyawa yang dapat menghambat reaksi oksidasi dengan mengikat radikal bebas dan molekul yang sangat reaktif sehingga kerusakan sel akan di hambat. Pereaksi yang digunakan adalah larutan DPPH. DPPH (2,2-difenil-1-pikrilhidrazil) merupakan senyawa radikal bebas berwarna ungu apabila senyawa tersebut dilarutkan dalam etanol atau metanol, dan apabila bereaksi dengan senyawa peredam radikal bebas akan memucatkan warna ungu dari larutan. DPPH merupakan radikal bebas yang memiliki elektron yang tidak berpasangan. Diphenylpicrylhydrazyl mempunyai satu atom N yang elektronnya tidak berpasangan dan apabila bereaksi dengan senyawa peredam radikal bebas akan terjadi pengikatan satu elektron atom $\mathrm{N}$ membentuk diphenylpicrylhydrazyn yang stabil. Pengujian dilakukan dengan mengelusi masing-masing plat KLT yang telah ditotolkan dengan masing-masing fraksi isolat. Fraksi isolat yang digunakan adalah fraksi $\mathrm{B}_{2.1}, \mathrm{~B}_{2.2}$ dan $B_{2.3}$ sedangkan cairan pengelusi yang digunakan adalah klorofrom : metanol (25:1). Plat KLT hasil elusi selanjutnya disemprot dengan larutan DPPH dan didiamkan beberapa saat. Fraksi dinyatakan positif memiliki aktivitas antioksidan jika terdapat peredaman pada lempeng KLT, yaitu perubahan warna dari ungu menjadi putih pucat . Hasil pengujian antioksidan dilihat pada Tabel 2. 


\begin{tabular}{|c|c|c|c|}
\hline $\begin{array}{l}\text { Fraksi Isolat } \\
\text { (Eluen) }\end{array}$ & Aktivitas Antioksidan & Noda & Nilai Rf \\
\hline \multirow{3}{*}{$1: 10\left(\mathrm{~B}_{2.1}\right)$} & \multirow{3}{*}{+} & 1 & 6.5 \\
\hline & & 2 & 4.5 \\
\hline & & 3 & 1 \\
\hline \multirow{3}{*}{$1: 2\left(\mathrm{~B}_{2.2}\right)$} & \multirow{3}{*}{+} & 1 & 5.5 \\
\hline & & 2 & 4 \\
\hline & & 3 & 1 \\
\hline \multirow{3}{*}{$1: 1\left(\mathrm{~B}_{2.1}\right)$} & \multirow{3}{*}{+} & 1 & 7 \\
\hline & & 2 & 5 \\
\hline & & 3 & 1 \\
\hline
\end{tabular}

Keterangan Tabel 2 :

(+): Memberikan aktivitas terhadap DPPH

(-) : Tidak memberikan aktivitas terhadap DPPH

\section{Kandungan Metabolit Sekunder Aktif}

Metabolit sekunder merupakan senyawa yang tidak esensial bagi pertumbuhan organisme. Senyawa metabolit sekunder merupakan produk alami atau senyawa alam yang eksistensinya tidak begitu penting dalam tubuh tapi berperan penting pada kelangsungan hidup suatu makhluk hidup. Sebagian besar tanaman penghasil senyawa metabolit sekunder memanfaatkan senyawa tersebut untuk mempertahankan diri dan berkompetisi dengan makhluk hidup lain disekitarnya. Adapun kandungan metabolit sekunder yang akan diuji pada fraksi isolat $\mathrm{B}_{2.1}, \mathrm{~B}_{2.2}$ dan $\mathrm{B}_{2.3}$ daun tendani diantaranya adalah alkaloid, flavanoid, steroid, terpenoid dan fenolik. Deteksi alkaloid menggunakan pereaksi Dragendrof hasil positif terbentuk warna kuning pekat pada noda, uji flavanoid menggunakan pereaksi timbal asetat $25 \%$ hasil positif ditunjukan dengan pada spot yang disinari dengan UV $366 \mathrm{~nm}$, deteksi steroid menggunakan pereaksi asam fosfat $85 \%$ hasil positif berupa bercak tampak berwarna merah tua setelah pemanasan, deteksi triterpenoid menggunakan pereaksi Lieberman Bouchardt reaksi positif berupa pendaran pada UV 366 $\mathrm{nm}$, uji fenol menggunakan pereaksi timah (IV) klorida reaksi positif berpendar pada UV $366 \mathrm{~nm}$. Deteksi metabolit sekunder aktif dilakukan berdasarkan deteksi aktivitas antibakteri dan reaksi peredaman DPPH dari spot pada lempeng KLT. Hasil metabolit sekunder aktif yang diperoleh pada fraksi isolat $\mathrm{B}_{2.1}$ adalah flavanoid, terpenoid dan fenolik, fraksi isolat $\mathrm{B}_{2.2}$ metabolit sekunder aktif yang didapat adalah flavanoid, steroid dan terpenoid sedangkan fraksi isolat $\mathrm{B}_{2.3}$ metabolit aktif yang didapat adalah terpenoid dan fenolik. Hasil identifikasi metabolit sekunder fraksi isolat daun tandani dapat dilihat pada Tabel 3.

Tabel 3 Hasil identifikasi golongan metabolit sekunder isolat daun tendani

\begin{tabular}{|c|c|c|c|c|c|c|c|c|c|c|c|c|c|c|c|c|}
\hline \multirow{3}{*}{ No } & \multirow{3}{*}{$\begin{array}{l}\text { Fraksi } \\
\text { isolat }\end{array}$} & \multirow{3}{*}{$\mathrm{Rf}$} & \multicolumn{14}{|c|}{ Metabolit Sekunder } \\
\hline & & & \multicolumn{2}{|c|}{$\mathrm{AKD}$} & \multirow[b]{2}{*}{$\mathrm{Rf}$} & \multicolumn{2}{|c|}{ FLD } & \multirow{2}{*}{$\mathrm{Rf}$} & \multicolumn{2}{|c|}{ STD } & \multirow{2}{*}{$\mathrm{Rf}$} & \multicolumn{2}{|c|}{ TPD } & \multirow{2}{*}{$\mathrm{Rf}$} & \multicolumn{2}{|c|}{ FNK } \\
\hline & & & $\mathrm{AB}$ & $\mathrm{AO}$ & & $\mathrm{AB}$ & $\mathrm{AO}$ & & $\mathrm{AB}$ & $\mathrm{AO}$ & & $\mathrm{AB}$ & $\mathrm{AO}$ & & $\mathrm{AB}$ & $\mathrm{AO}$ \\
\hline \multirow{3}{*}{1} & \multirow{3}{*}{$\begin{array}{l}1: 10 \\
\left(B_{2.1}\right)\end{array}$} & - & - & + & 6,5 & + & + & - & - & + & 6 & + & + & 6,5 & + & + \\
\hline & & - & - & - & 6 & + & + & - & - & - & 4 & + & + & 2,5 & + & + \\
\hline & & - & - & - & 4 & + & + & - & - & - & - & - & - & - & -- & - \\
\hline
\end{tabular}




\begin{tabular}{|c|c|c|c|c|c|c|c|c|c|c|c|c|c|c|c|c|}
\hline 2 & $\begin{array}{c}1: 2 \\
\left(\mathrm{~B}_{2.2}\right)\end{array}$ & - & - & + & 5 & + & + & 5 & + & + & 6,7 & + & + & - & - & + \\
\hline 3 & $\begin{array}{c}1: 1 \\
\left(\mathrm{~B}_{2.3}\right)\end{array}$ & - & - & + & - & - & + & - & - & + & 6,5 & - & + & 6,5 & + & + \\
\cline { 3 - 14 } & & & & & & & & & & & & & 4 & + & + \\
\hline
\end{tabular}

Keterangan Tabel 3:

Data berupa data kualitatif (-) dan (+), dimana:

$(-)$ : Tidak teridentifikasi golongan metabolit sekunder

$(+)$ : Teridentifikasi golongan metabolit sekunder

$\mathrm{AB}:$ Antibakteri

AO : Antioksidan

\section{KESIMPULAN}

Fraksi isolat etil asetat daun tendani memiliki aktivitas antibakteri terhadap bakteri Streptococcuc mutans, Staphylococcus aureus, Eschericia coli, Pseudomonas aeruginosa. Fraksi isolat etil asetat daun tendani memiliki aktivitas sebagai antioksidan dapat dilihat terjadi peredaman pada daerah spot noda plat KLT berdasarkan kemampuan peredaman DPPH pada lempeng plat. Kandungan metabolit sekunder aktif fraksi isolat etil asetat adalah flavanoid, steroid, terpenoid dan fenolik.

\section{SARAN}

1. Perlu dilakukan pengembangan eluen pada prosedur isolasi dengan menggunakan pelarut dan perbandingan yang lebih bervariasi.

2. Perlu isolasi senyawa aktif untuk mendapatkan senyawa tunggal.

\section{DAFTAR PUSTAKA}

Abdi, dkk. 2011. Formulasi Pasta Gigi Berbahan Aktif Ekstrak Daun Sirih Hitam Sebagai Antimikroba Penyebab Radang Gusi (Gingivitis) dan Gigi Berlubang (Caries). PIMNAS XXIV; Makassar.

Arianto Devy Agustina. Identifikasi Metabolit Sekunder dan Potensi Ekstrak Daun Tendani (Goniothalamus Macrophyllus Hook. F. \& Thoms) Sebagai Antioksidan. Universitas Mulawarman; Samarinda

Djide, N. M. dan Sartini. 2008. Analisis Mikrobiologi Farmasi. Lab. Mikrobiologi Farmasi UNHAS

Alifin Taufik A. 2011. Potensi Antibakteri Ekstrak Daun Tendani (Goniothalamus Macrophyyllus Hook.f. \& Thoms) Terhadap Bakteri Stapyylococcus aureus dan Psudomonas aeruginosa.,Universitas Mulawarman; Samarinda

Waluyo, Lud., 2008, Tekhnik Metode dasar dalam Mikrobiologi, UMM Press, Malang

Winarsi,Hery. 2006.Antioksidan Alami dan Radikal Bebas Potensi dan Aplikasi dalam Kesehatan. Yogyakarta. Kanisius 